\title{
Rethinking sustainable urban development: towards an integrated planning and development process
}

\author{
T. Yigitcanlar $\cdot$ S. Teriman
}

Received: 19 July 2013/Revised: 7 December 2013/Accepted: 21 December 2013/Published online: 14 January 2014

(C) Islamic Azad University (IAU) 2014

\begin{abstract}
A city is the most dramatic manifestation of human activities on the environment. This human-dominated organism degrades natural habitats, simplifies species composition, disrupts hydrological systems and modifies energy flow and nutrient cycling. Sustainable urban development (SUD) is seen as a panacea to minimise these externalities caused by widespread human activities on the environment. The concept of SUD has been around over a considerably long time as the need to adopt environmentally sustainable behaviours made the international community commit to it. However, to date such development has not been achieved in large scales anywhere around the globe. This review paper aims to look at the SUD concept from the lens of planning and development integration to generate new insights and directions. The paper reports the outcome of the review of the literature on planning and development approaches-i.e. urban planning, ecological planning, urban development, SUD-and proposes a new process to support the efforts for achieving SUD-i.e. integrated urban planning and development process. The findings of this review paper highlight that adopting such holistic planning and development process generate a potential to further support the progress towards achieving sustainability agendas of our cities.
\end{abstract}

\section{T. Yigitcanlar $(\bowtie)$}

School of Civil Engineering and Built Environment, Queensland University of Technology, 2 George Street, Brisbane,

QLD 4001, Australia

e-mail: tan.yigitcanlar@qut.edu.au

\section{S. Teriman}

Faculty of Architecture, Planning and Surveying, University Technology MARA, Seri Iskandar, 32610 Bandar Baru Seri Iskandar, Perak, Malaysia
Keywords Ecosystem consideration · Integrated urban planning and development process - Sustainability . Sustainable urban development · Urban development process $\cdot$ Urban planning process

\section{Introduction}

The concept of sustainability has been pushed to the forefront of policymaking and politics as the world wakes up to the impacts of climate change and the effects of the rapid urbanisation and modern urban lifestyles (Wheeler and Beatley 2004; Hamin and Gurran 2009; Zhao 2010). Climate change and fossil fuel-based energy policy have emerged as the biggest challenges for our planet, threatening both built and natural systems with long-term consequences (Hennicke 2005; Meehl et al. 2007; Liao et al. 2013). However, the threats are not limited to the impacts of climate change and unsustainable energy system onlye.g. impacts of rapid urbanisation, socioeconomic crises, governance hiccups are just to name a few (Jabareen 2006; Yigitcanlar 2010a). Along with these challenges, successfully coping with the enormous transformations that our cities, societies and the environment have been going through during the last few decades, and their consequential impacts we are facing today, call for a more effective and resilient planning and development perspective (Pickett et al. 2004). Scholars across the globe see 'sustainable urban development' (SUD) as a contemporary paradigm to address these challenges and provide an opportunity to form new mechanisms for building a desirable urban future (Luck 2007; Yigitcanlar et al. 2008; Runhaar et al. 2009). SUD is perceived as improving the quality of life in a city, including ecological, cultural, political, institutional, social and economic components 
without leaving a burden-e.g. the result of a reduced natural capital and an excessive local debt, on the future generations-and thus forming the sustainable city (Jenks and Dempsey 2005; Yigitcanlar 2010b; While et al. 2010; Flint and Raco 2012).

In the twenty-first century, urban sustainability has become a prominent element in the day-to-day debate on urban policy and the expression of sustainability policy in urban and environmental planning and development decisions (Pezzey 2004; Wheeler 2004; Dovers 2005). Whilst the origins of the sustainability discussion date back to the work of the Club of Rome, the Bruntland report and the Rio declaration, in recent years, its critical importance has been highlighted through the adverse impacts of human activities-such as a rapidly changing climate and the severe effects of greenhouse gas emissions (Meadows et al. 1972; Redclift 2005). In an atmosphere where civilisation is progressing and becoming more aware of the consequences of inconsiderate urban development decisions, rethinking SUD has become an inevitable necessity (Bulkeley and Betsill 2005; Yigitcanlar et al. 2007a). The provision of a built environment that is sustainable-and linked with and enhanced through natural environment-is still a central challenge for contemporary urban governance (Rydin 2010). Today, technology is purported as a panacea to all sustainability problems (De Coninck et al. 2008; Lee et al. 2008; Yigitcanlar and Lee 2013). However, answers to these problems should not be sought by just relaying on technology solution availability only. Even though in planning for SUD, technology applications are frequently utilised (Geertman et al. 2013); the rethinking of SUD is critical (Williams et al. 2000; Yigitcanlar 2010a).

The need to protect the environment from the excessive ecological destruction of unregulated economic growth and conspicuous consumption is unquestionable, and with a common consensus, SUD is seen as the main vehicle for such protection (Burton et al. 2004: Teriman et al. 2009). However, to date, unfortunately, implementation of SUD in a large city scale and the construction of sustainable cities could not be realised (Doughty and Hammond 2004; Kenworthy 2006; Moore 2007). This calls for a reassessment of the mechanisms involved in SUD implementation-such as urban planning and development processes (Rotmans and Van Asselt 2000). Thus, the paper, firstly, reviews the literature on urban planning and development theories, approaches and methods-i.e. urban planning, ecological planning, urban development and SUD-and provides an overall outlook of the current viewpoints. This paper, then, proposes a new process to support the efforts for achieving SUD-i.e. integrated urban planning and development process. The paper argues the benefits of the proposed holistic and integrated approach particularly for urban administrations to see and appreciate the big picture view of SUD, and take necessary actions for wider and successful implementation of the sustainability agenda. The discussion and conclusion sections exhibit future directions in SUD, and thus support moving one step closer to achieve desirable sustainability outcomes for our cities.

\section{Materials and methods}

\section{Urban planning process}

The public authority-oriented urban planning of the 1950s is based on rational planning thinking, one of the major traditions in Planning Theory (Campbell and Fainstein 2003; Fainstein 2005). It refers to a set of planning processes for selecting and implementing the best possible plan from a number of alternatives. This concept sets out a formal planning process in plan making denoted by a number of steps or courses of action. According to Schonwandt (2008), this model constitutes four essential steps: (1) analysing the situation, (2) establishing goals, (3) formulating possible courses of actions and (4) comparing and evaluating the consequences of the actions. This approach represents what planners believe is rational or to plan with reason. Rationality refers to how we use reasons to guide choices, and argues that people would not support plans lacking reason, because such reason justifies the content of the plans, and offers rational advice about what to do for the future (Fainstein 2000; Allmendinger 2009).

Lawrence (2000) argues that the rational urban planning concept has been central to the evolution of modern urban planning, and its application has resulted in the development of Master Planning and Comprehensive Planning. This concept offers a systematic forward progression from goal setting to forecasting the impact of alternatives; and from the selection of alternatives that best achieve public goals to implementation; and then receive back again through a feedback loop (Schonwandt 2008). Using the same basic principles, various scholars have designated these steps in different ways, some refining them more acutely. Berke et al. (2006), for example, discuss the model as an eight-step process involving: (1) issues identification, (2) goals formulation, (3) data collection and analysis, (4) objective determination, (5) alternative consideration and plan evaluation, (6) plan selection, (7) plan implementation and (8) outcome monitoring. This process also includes an interlinked environmental review process, although in practice such review process generally either has not been 


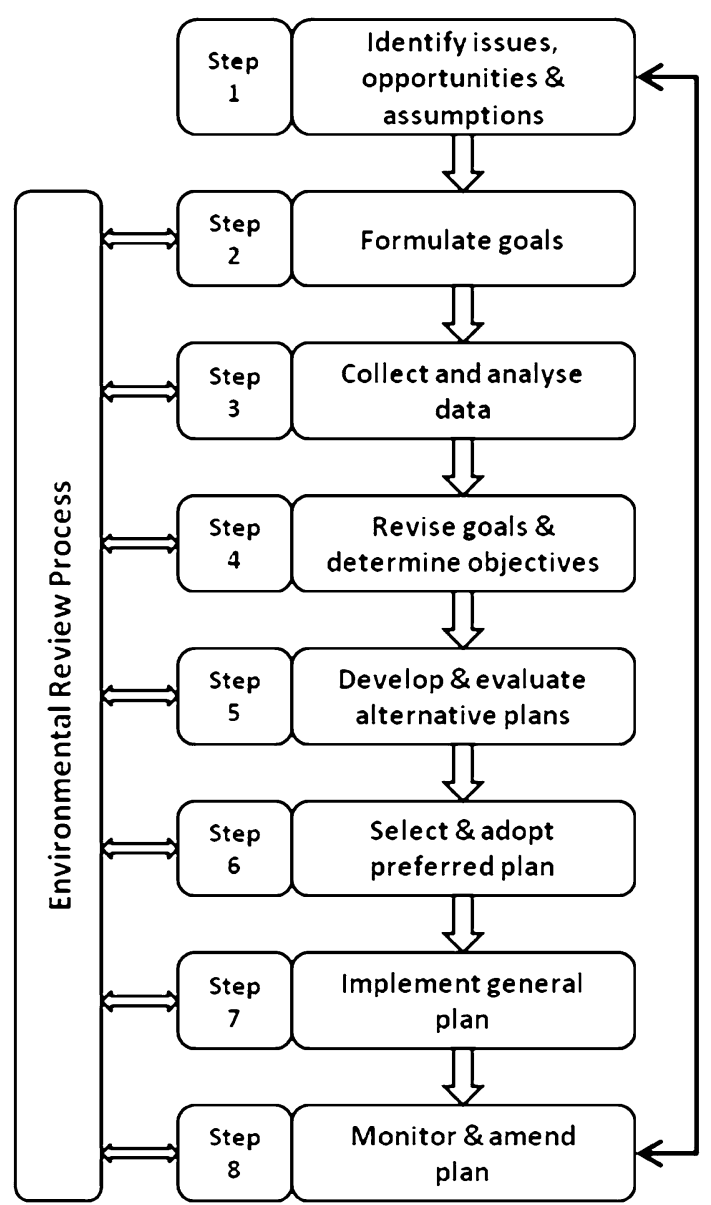

Fig. 1 Rational urban planning process (modified from Berke et al. 2006)

put into use at all or not done much positive impact (Fig. 1).

Since its inception, the rational urban planning approach has been a dominant planning paradigm and received widespread support and application (Schonwandt 2008). Historically, the application of the model was mainly limited to spatial planning area-i.e. built and natural environments-but in recent applications, it is extended to include social and economic, as well as public policy, politics and corporate planning issues. The rational urban planning approach provides systematic and consistent connection and relationships between each step of the process, utilising logic and evidence in analysing planning issues and proposals, as well as providing a sensible way of anticipating the future through its continuous review along the process (Berke et al. 2006).

According to proponents, the other characteristics of rational urban planning include systematic applications of reasoning, bringing forth unitary public interests, providing a controllable environment and enabling the implementation of the final plan-making process. One characteristic that stands out, especially amongst practitioners, is that the role of planners as expert advisors is well defined (Lawrence 2000). Owing to these practicalities, rationalism is currently being applied in most general and sectoral plans, where it takes into account the descriptive courses of action that ought to be taken during the process and allows for the inclusion of various facilities and land requirements to accommodate changes or forecast variables including population, economy, natural resource conditions and housing needs (Berke et al. 2006; Teriman 2012).

Opponents of the rational planning approach, however, have listed a number of criticisms of the approach. Lawrence (2000), for example, argues that in considering alternative plans, the use of assumptions and logic-based on expert opinions, and when not being disclosed to the public, will have a tendency to invite public opposition as these plans may not be compatible with public concerns and values. Furthermore, he purports that rationalism is weakened when implemented because it neglects the central role of dialogue in planning and fails to integrate substantive issues, such as social and environmental needs in the design process (also see Farr 2012). Lawrence (2000) claims that the model tends to overestimate the ability to predict and control the environment, as it relies on the consequences of trends and emerging conditions to give numerical projections of future accounts, and not the more meaningful, mental picture or inspirational view of what the future is going to be. Berke et al. (2006) contend that the criticisms directed at rationalism-could not be justified if the rational urban planning approach-were to incorporate various aspects of consensus building and the participatory design models of planning. Furthermore, in the SUD discourse, rational urban planning is criticised for not being capable of generating realistic plans for sustainable futures including procedures to take urban ecosystems into consideration during the plan-making stages (Vasishth 2008) — even though there are some promising attempts in planning for sustainability of our cities (Cheng and $\mathrm{Hu} 2010$ ).

\section{Ecological considerations in urban planning}

Urban planning was traditionally carried out to achieve spatial development objectives that the promotion of a sustainable urban future was not often incorporated into the process (Naess 2001). As a result, it is argued that the planning process did not provide a satisfactory means of protecting the environment, especially from the negative cumulative environmental effects of development and expansion of urban areas (Neufeld et al. 1994; Alberti 2005). Attempts to include planning with ecological principles and green design have been around for about 


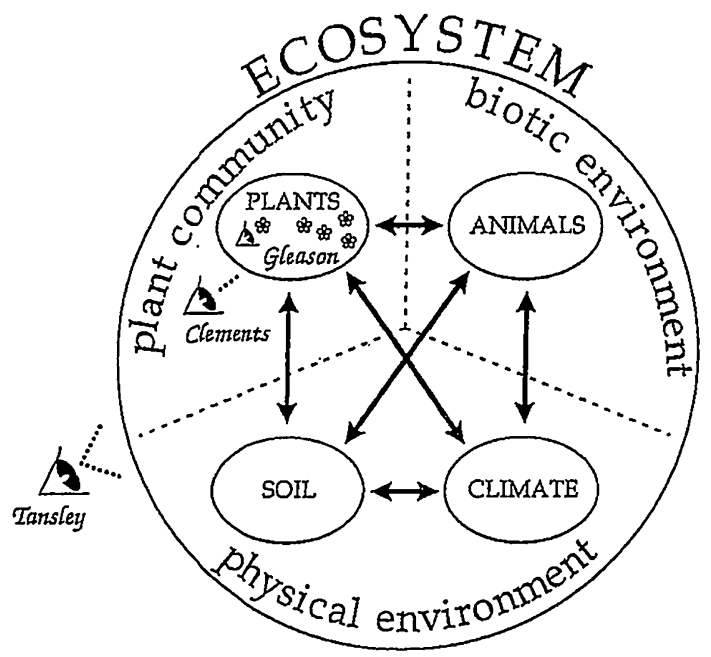

Fig. 2 Tansley's ecosystem view (modified from Vasishth 2008)

four decades (Pickett et al. 2001; Rydin 2003). However, as Berke et al. (2006) argue, the ideal of green communities of the early twentieth century did not take root in the contemporary planning practice. Even though the increasing consensus pointed to the positive effects of the green dimension towards sustainable urban form, efforts to integrate this dimension into the building of human settlements are far from effective (Berke and Conroy 2000).

Notwithstanding, the drive towards a sustainable urban future must also take account of our ecosystem, upon which we ultimately depend. The importance of a functioning ecosystem-including the human existence in such ecosystem-is well recognised within the concept of sustainability and ecological integrity (Ridd 1995). However, so far the common tendency in improving human wellbeing and quality of life has been threatening this integrity. The urban environmental transition theory suggests that urban development expansion leads to a series of environmental challenges, which are often localised, immediate and health threatening (Elzen et al. 2004; Berke et al. 2006). However, as cities expanded and increased in affluence, these challenges have now become global, long term and ecosystem-threatening and may jeopardise the future sustainability or healthy existence of the entire world ecosystem (Rapport et al. 2009). The transition of ecological planning, from nature to community, was first recognised by Arthur Tansley, who in 1935, proposed the ecosystem concept, which incorporates components from all plant communities, the biotic environment and the physical environment-see ecosystem boundaries in Fig. 2 (Vasishth 2008). In other words, Tansley expounded that it is the relationships between organisms and their environment that provides the perspective for ecology (Pickett and Grooge 2009).
Odum (1989) enhances the ecosystem concept to the whole environment, including urban system, and argues that the built environment received energy and material flows at a faster rate than the natural environment. Lyle (1994) makes Odum's concept more operational in a planning sense by introducing the human ecosystem in which he maintained that human advancement has compromised nature and is continuously replacing the efficient ecosystem with an inefficient system that threatens our source of sustenance. Lyle (1994) also introduces the term regenerative technology, which replaces and alters the materials and energy that humans use, and integrates art and science to optimise the ability of nature to regenerate.

An ecosystem approach to urban planning processes provides systematic guidance on the interrelationship between human activities and ecosystem health (Tzoulas et al. 2007; Wu 2008). This approach places an importance on the ecological context in policy and decisionmaking and the evaluation of the human-natural relationship. In other words, it treats ecological goals equally to and simultaneously with economic and social goals, and, further, acknowledges that there is a limit to the degree of stress ecosystems can accommodate before they are irreversibly degraded or destroyed (Neufeld et al. 1994). An important aspect of this approach is the adaptive management strategy-rule and management criteria flexible enough to handle changing biophysical and human-related events, and shifting goals (Shepherd 2004).

Neufeld et al. (1994) state that the ecosystem approach includes five major interdependent components: (1) boundaries for planning purposes - use of biophysical boundaries within which human-nature interaction is assessed; (2) environmental objectives and targetsfocusing on protection and natural regeneration of ecosystem; (3) evaluation of cumulative environmental effects; (4) information collection and management; and (5) monitoring-objective achievements and effectiveness of planning decisions (Fig. 3). The ecosystem approach provides a promising technique. It uses ecosystems as the regional units for planning, and integrates biophysical issues with social and economic issues. Moreover, a more efficient development review process or evaluation can be realised through the ecosystem planning approach, because it delivers better upfront guidance on the location, type and timing of development. Neufeld et al. (1994) advocate that the integration of ecosystem considerations into planning promotes urban sustainability initiatives, as it prevents development decisions from jeopardising the future ecosystem and human health. Therefore, where the ecosystem and human health remain intact, potential costly and difficult 


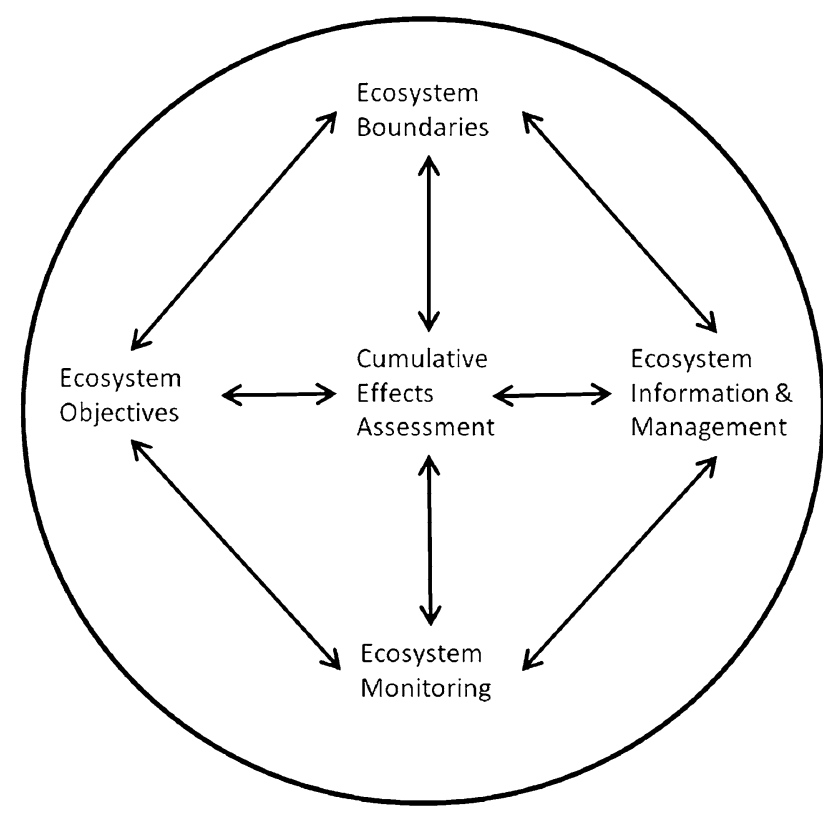

Fig. 3 Interdependent components of ecosystem approach (modified from Neufeld et al. 1994)

remedial actions can be avoided (Teriman and Yigitcanlar 2011). In the light of the ecological considerations in planning, Niemela (1999) emphasises that ecological information needs to be seriously considered in urban planning to ensure SUD.

\section{Urban development process}

Clarke (1995) argues that the traditional urban planning approach has been often ineffective because too much emphasis has been put on policy and plan making, whilst on the implementation or development side, the emphasis has been comparatively less. In attempting to highlight the importance of the implementation issue, four different types of model are identified to represent the general development process: (1) the equilibrium model of neoclassical economies; (2) the event-sequence model from an estate management perspective; (3) the agency model from an institutional perspective; and (4) the structure model, which is grounded in urban political economy. However, when considering the land or urban development process, these models lack specific focus on planning related implementation. Gore and Nicholson (1991) underline that the nature of the urban development process is very complex and no single model can entirely represent such a process. Notwithstanding, one interesting model that depicts the relationship between the planning and development process, and focuses on the sequence of events of this process, is the event-based development model (Adams 1994; Teriman 2012).
An event-based approach to the urban development process has four distinct phases: (1) evaluation, (2) preparation, (3) implementation and (4) disposal (Adams 1994). One of the best event-based models is the development pipeline concept (Fig. 4). This model reduces the multiplicity of the development process into three broad events, starting with development pressures, subsequently, development feasibility and finally implementation (or development), which includes construction and transfer of completed development (Chen and Jiang 2000). In practice, the model operates as a spiral, producing a fresh pattern of land-use at the end of each cycle, therefore, highlighting the dynamic nature of the development process. Figure 4 shows the initial development pressures and prospects all constitute part of the planning stage. In fact, the implementation process starts towards the end of the development feasibility section, involving evaluation of physical and market conditions, and proceeds with legal and administrative procedures prior to construction on the ground. Upon completion of the construction phase, the project moves into the final stages of delivery and onto purchasers for occupation. This completes the full cycle of the implementation process (Teriman 2012).

Ratcliffe and Stubbs (2013) criticise the urban development process for majority of emphasis being given to real estate development, even if in recent years, there is better linkage between planning and development stages. Furthermore, as it is the case in the development process, the sustainability issue - and SUD — has not been in the primary focus of urban development industry-excluding some limited best practice initiatives (Ortiz et al. 2009; Yigitcanlar et al. 2010). This is mainly due to the lack of effective planning and development coordination and control, in other words, lack of having a comprehensive approach in integrating urban planning and development processes with the notions of ecosystem perspective and sustainability principles (Teriman 2012). Thus, achieving SUD requires a new planning and development process.

\section{Results and discussion}

Rethinking sustainable urban development: towards a system approach

Based on the previous reviews, it can be claimed that rational urban planning process and event-based development process fundamentally two distinctive, but interrelated processes. The ecosystem approach, on the other hand, reflects the growing concerns for the sustainability (Fiksel 2006). Proponents of Ecosystem Theory (Muller 1992) suggest that the development process should take 
Fig. 4 Event-based development process (modified from Adams 1994)

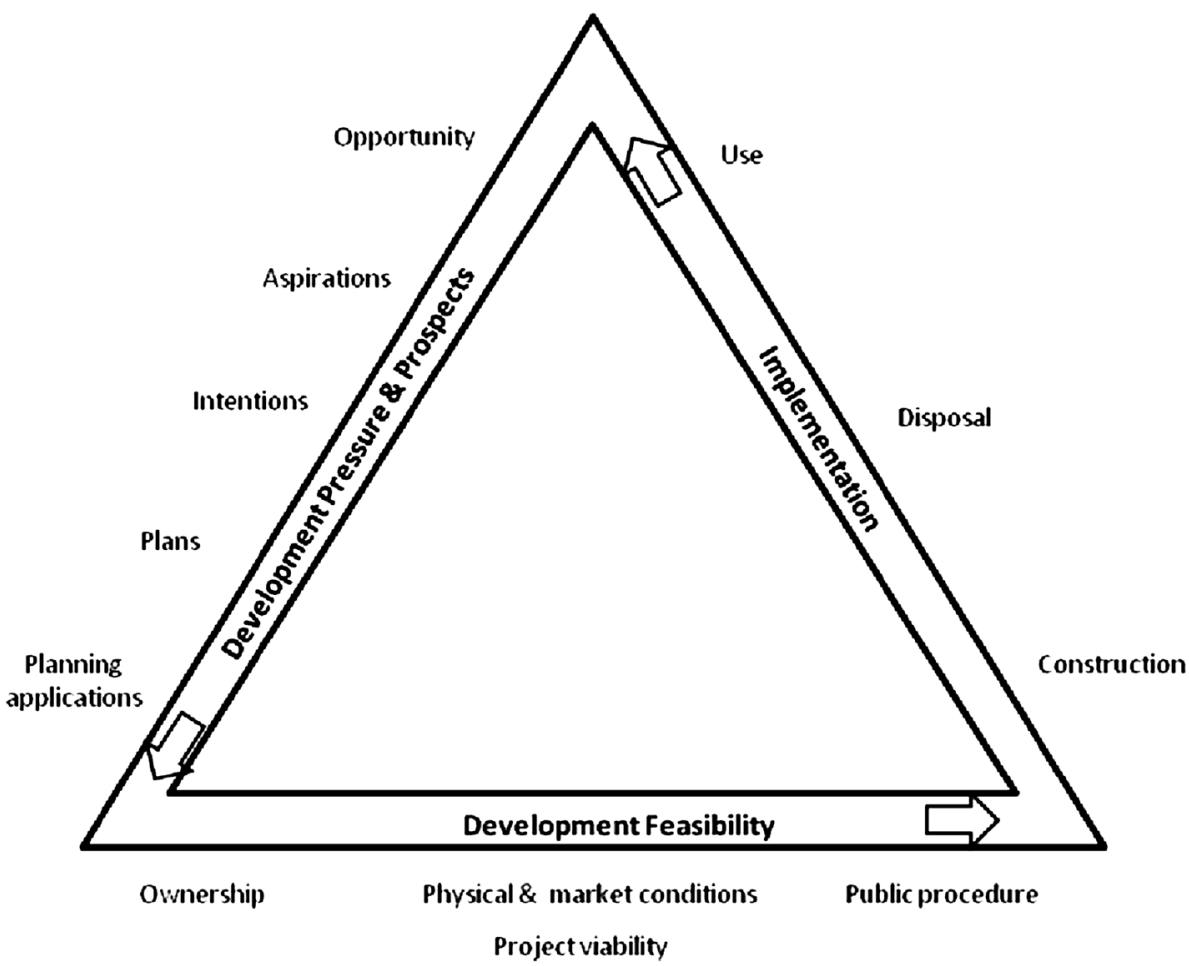

place within the limit of what the ecosystem can withstand (Zhang et al. 2006). In other words, urban planning and development processes should operate within the limits of the ecosystem boundary in order to achieve sustainability in the long run. According to (Fiksel 2006, p. 20), "[s]ustainable [urban] development in a changing global environment will require resilience at many levels...[W]e need to develop adaptive policies and strategies that enable societal and industrial institutions to cope with unexpected challenges, balancing their need to flourish and grow with long-term concerns about human and ecological wellbeing. In particular, addressing the challenge of global warming will require unprecedented international cooperation in both the development of alternative technologies and adaptation to climate change impacts". On that very point, along with resilience, system approach thinking should be adopted all across the plan and policymaking circles of our cities.

The first step of adopting system approach involves integration of the three key components-i.e. planning, development and ecosystem sustainability-into a single urban planning and development process to create a sustainability-oriented urban planning and development culture. Attempts of such integration have already been taking place mainly by using simulation models-e.g. integrated urban development and ecological simulation model (Alberti and Waddell 2000). In this regard, planners-who in general see themselves as defenders of socioeconomic equality-now may see their roles further enhanced: as reconciling agents in promoting economic growth; in ensuring physically balanced growth distributions and in ensuring the protection of the ecosystem (Campbell 2003). However, this is a challenging role, as planners need some form of sustainability assessment mechanism integrated into the planning process. The purpose of such assessment is to determine whether the activities undertaken within each stage in the development process contribute to the targeted sustainability goals (Karol and Brunner 2009; Mascarenhas et al. 2010).

Sustainability assessment is increasingly being viewed as an important tool to monitor the human-environment interaction at different temporal and spatial scales-in other words assessing SUD levels from micro to macro levels, from building/parcel to nation (Ebert and Welsch 2004). It provides valuable information to assess the performance of the existing economic, social and environmental policies, plans and programmes by highlighting 
emerging issues or problems (Devuyst et al. 2001; Nguyen 2004; Yigitcanlar and Dur 2010; Dur and Yigitcanlar 2014). Furthermore, it contributes to the development of sustainable policies in terms of collecting information for planners and policymakers concerning the severity of environmental problems and their impacts on natural systems (Alberti 1996; Newman and Jennings 2008). In sustainability assessment, indicators are commonly employed tools (Hacking and Guthrie 2008). Sustainability indicators are essential tools to support SUD, as the use of indicators is a fundamental step to guide the decision process ( $\mathrm{Li}$ et al. 2009; Gasparatos 2010). Mayer (2008) and Singh et al. (2009) provide the strengths and weaknesses of common sustainability indices used for SUD assessment in detail.

There are, fortuitously, numerous SUD assessment methodologies, measuring different sustainability dimensions of the built and natural environments, available for planners-i.e. 'land-use and public transport accessibility indexing model' (LUPTAI), 'sustainable infrastructure land-use environment and transport model' (SILENT)', 'Micro-level Urban-ecosystem Sustainability IndeX' (MUSIX) and 'integrated land-use and transport indexing model' (ILTIM) (Yigitcanlar et al. 2007b; Yigitcanlar and Dur 2010; Dizdaroglu et al. 2012). Beyond these, there are many other models developed to measure different aspects of SUD. For instance, Navabakhsh and Tamiz (2013) introduce sociocultural indices with a number of indicators to measure the influences of industries on sustainable social and environmental developments. Tuzkaya (2009) uses an integrated methodology with indicators to evaluate the environmental impacts of alternative transportation modes. Alam et al. (2006) develop an environmental degradation index to assess the impacts of unplanned urbanisation. Rassafi and Vaziri (2005) propose a SUD assessment model with large number of sustainable transport indicators aggregated into several composite indices. Mahbub et al. (2011) construct a mathematical model measures the pollutant load levels in urban ecosystems-particularly in urban water catchment areasthat feeds into an indicator-based urban sustainability indexing model. Mori and Christodoulou (2011) offer an extensive review of the most common sustainability indices and indicators.

Integrated urban planning and development process

The aforementioned literature findings suggest the need for a system approach and an integrated urban planning and development process to deliver SUD outcomes for our cities. In order to provide an example of how an integrated planning and development process looks like, we developed an exemplar integrated urban planning and development process, which its diagram is illustrated in Fig. 5. In such process, each component includes a list of criteria or variables, some of which require particular evaluation techniques. This process begins with defining the planning issues and goals (Step 1), which may involve any one or all three aspects-i.e. environmental, social and economic. Once identified, the goals and objectives are refined in Step 2, taking into account the priority ones. In Step 3, alternatives are generated, and based on the achievement of selected goals and intended objectives. In Step 4, these alternatives are thoroughly assessed, subsequent to a collaborative understanding between experts and the stakeholders. Sustainability is amongst the primary criteria of the assessment (Teriman 2012).

In this exemplar process, once the best alternative is selected, it goes through the first round of sustainability evaluation, with the purpose of ensuring that it meets the sustainability criteria or levels being set. In the case that it falls short of this assessment, the selected alternative or plan to be returned to the stages where the shortfall occurs. If, however, it meets the evaluation requirement, the alternative or plan goes to the beginning of implementation process (Step 5), involving a feasibility evaluation of the proposed development. It then proceeds to the construction stage (Step 6), where various administrative procedures and funding arrangements should be met and organised. Construction progress is regularly monitored to ensure compliance with the development plans and financial resources. In Step 7, the construction project to be completed and upon finalisation of paperwork and administrative procedures, the project is delivered. Finally, in Step 8, a fixed period is set for monitoring the just delivered or commissioned project to ensure any defects and deficiencies arising from the construction of the project are remedied (Teriman 2012).

In this process, the second round of sustainability assessment takes place after Step 8, but not until the project has been occupied or is in operation for a certain acceptable period, where the users have been well adapted to the development and environment around them. Compliance with sustainability evaluation characteristics means such projects are contributing towards a sustainable urban future whilst non-compliant projects to be subject to a re-evaluative process, for future project improvement. For existing projects, the re-evaluation may require retrofitting be undertaken where applicable. Additionally, management is a critical component of this 
Fig. 5 Proposed integrated urban planning and development process (modified from Teriman 2012)

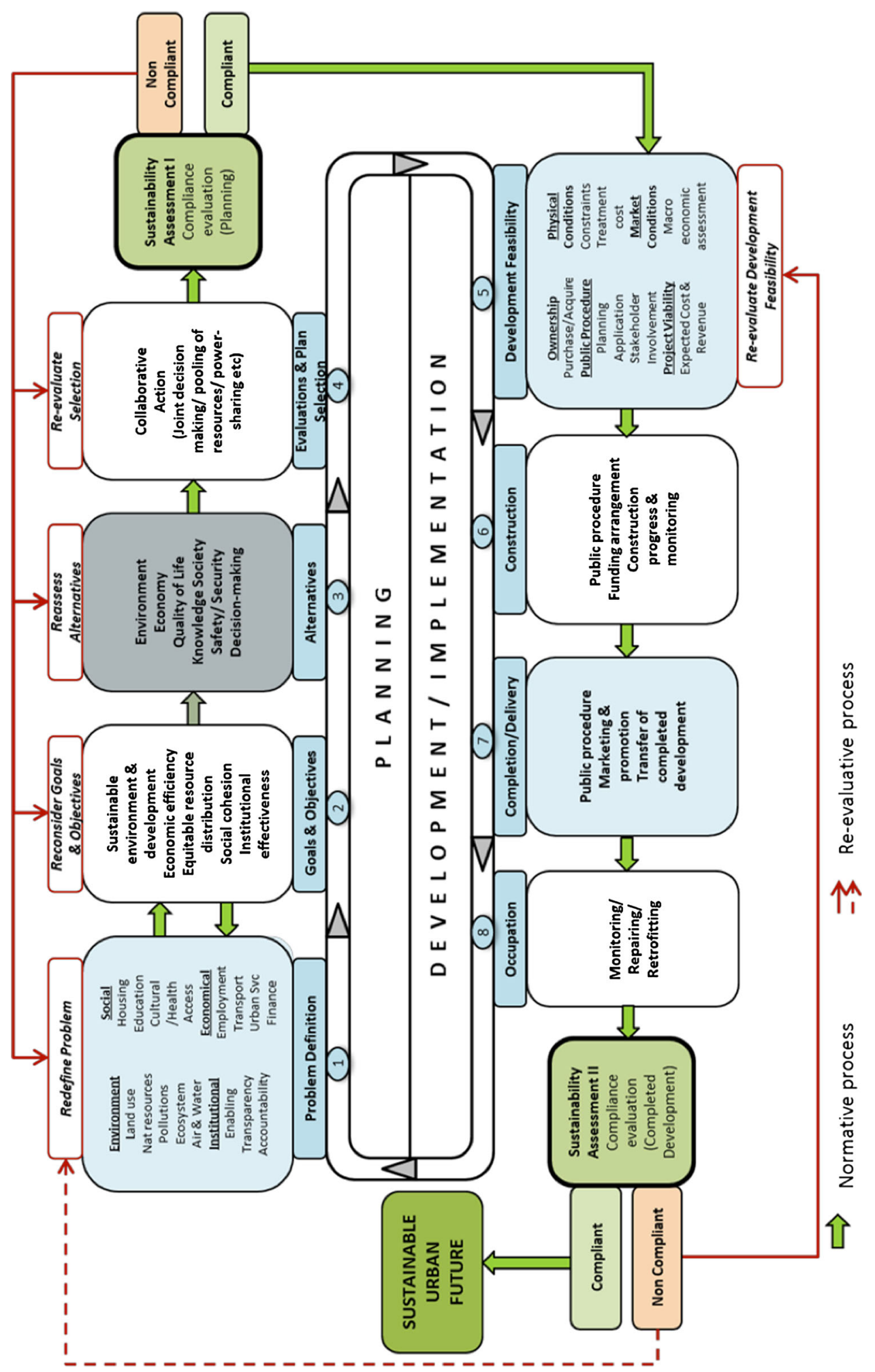

process, particularly preparation of risk management plans (Peptenatu et al. 2011), strategic planning matrices (Nouri et al. 2008), information policy and management frameworks (Chen et al. 2010), and knowledge management tools (Huang and Shih 2009) are essential for a successful SUD practice. 
It should be noted, however, that in consideration of the differing views on planning and development processes put forward by the various researchers, the addition of consensus building and participatory design efforts is necessary to rectify the shortfalls of the rationalist philosophy. Indeed, consensus building has become the reigning paradigm in the Planning Theory since the 1990s as it brings together major stakeholders to address controversial issues and to reach an agreement on these issues-including sustainability matters. Furthermore, this approach supports a shift in the role of planners, from one of merely providing expert opinion and technical leadership, to another important role of mediating between and communicating with stakeholders.

In the era of increasing concern for sustainability in the natural and built environments, an integrated framework that incorporates both rationalised planning and development processes, executed within the limitations of the ecosystem, can be seen as one way of continuing the urbanisation process in a sustainable manner. This may also help in generating a holistic SUD practice inspired from system approach thinking. Furthermore, by having a thorough sustainability assessment throughout the process, the public would be able to know whether sustainability elements exist at the planning and implementation stages and, if so, whether they, have really been achieved and implemented, and appreciated by the end user. Furthermore, such an integrated framework enables the community to create, implement and adapt plans that progressively guide change in ways that balance the goals of SUD. Any shortcomings identified in the assessment stage can be rectified via re-evaluating the specific stage of the development process where the shortcomings emerge.

\section{Conclusion}

The integrated urban planning and development process introduced in this paper along with Bentivegna et al.'s (2002) suggestion on a healthy SUD process requiring integration between urban assessment, planning, development and management processes strategically aligned with sustainability principles provides a new direction for rethinking SUD. Besides the integration issue, achieving SUD aimed for establishing sustainable cities requires adequate infrastructure, flexibility to support the needs of its population for the present and future generations and maintain the sustainability of its ecosystems. Improving urban ecosystems and the quality of life of citizens and places have become a central issue in the global effort of creating SUD. Especially as a great deal of world population is now living in cities and the urbanisation trend in both developed and developing countries is following an upward trajectory, many of the rapidly growing cities are developing strategies in becoming more sustainable. Urban settings have substantial impacts on people's lifestyles, behaviours and consumption patterns. Therefore, a development that is sustainable is crucial not only for increasing the liveability of cities, but also for maintaining the existence of urban ecosystems. The incorporation of sustainability in an urban context is so far centred upon density, urban form, urban design, and infrastructure, and amenities. The common current policy perspective is based on the idea that we can shape a city's development and vitality principally by containing and constraining the density and location of its land-uses and development. However, the past urbanisation experience alerts us to the need for paying much more attention to the way our investment in the built environment is central to our capacity to invent, innovate, adapt, become more competitive and at the same time protect and enhance the natural environment. In this instance, we need to rethink SUD and act accordingly before it is too late. Focusing on an integrated urban planning and development process seems to be a good way for progress in this direction, which is well aligned with system approach thinking originated from the Systems Theory (Bertalanffy 1969). This new planning and development approach helps urban administrations to see and appreciate the big picture view of SUD, take necessary actions for wider and successful implementation of the sustainability agenda, and consequently, move us one step closer to achieve desirable sustainability outcomes.

Acknowledgments We would like to thank our institutions for supporting our research. We also acknowledge and cordially thank the Editor-in-Chief Professor M. Abbaspour and anonymous reviewers for their constructive comments and suggestions, which helped us to improve the manuscript.

\section{References}

Adams D (1994) Urban planning and the development process. Routledge, London

Alam J, Alam B, Rahman M, Khan S, Munna G (2006) Unplanned urbanization: assessment through calculation of environmental degradation index. Int J Environ Sci Technol 3(2):119-130

Alberti M (1996) Measuring urban sustainability. Environ Impact Assess Rev 16(1):381-424

Alberti M (2005) The effects of urban patterns on ecosystem function. Int Reg Sci Rev 28(2):169-192 
Alberti M, Waddell P (2000) An integrated urban development and ecological simulation model. Integr Assess 1(3):215-227

Allmendinger P (2009) Planning theory. Palgrave MacMillan, Basingstoke

Bentivegna V, Curwell S, Deakin M, Lombardi P, Mitchell G, Nijkamp P (2002) A vision and methodology for integrated sustainable urban development: BEQUEST. Build Res Inf 30(2):83-94

Berke P, Conroy M (2000) Are we planning for sustainable development? An evaluation of 30 comprehensive plans. J Am Plan Assoc 66(1):21-33

Berke P, Godschalk D, Kaiser E (2006) Urban land-use planning. University of Illinois Press, Chicago

Bertalanffy L (1969) General systems theory. George Braziller, London

Bulkeley H, Betsill M (2005) Rethinking sustainable cities: multilevel governance and the urban politics of climate change. Environ Polit 14(1):42-63

Burton E, Jenks M, Williams K (eds) (2004) The compact city: a sustainable urban form?. Routledge, London

Campbell S (2003) Green cities, growing cities, just cities: urban planning and the contradictions of sustainable development. In: Campbell S, Fainstein S (eds) Readings in planning theory. Blackwell, Malden, MA

Campbell S, Fainstein S (eds) (2003) Readings in planning theory. Blackwell, Malden, MA

Chen J, Jiang J (2000) An event-based approach to spatio-temporal data modeling in land subdivision systems. GeoInformatica 4(4):387-402

Chen H, Yu R, Liaw S, Huang W (2010) Information policy and management framework for environmental protection organization with ecosystem conception. Int $\mathrm{J}$ Environ Sci Technol 7(2):313-326

Cheng H, Hu Y (2010) Planning for sustainability in China's urban development: status and challenges for Dongtan eco-city project. J Environ Monit 12(1):119-126

Clarke G (1995) Re-appraising the urban planning process as an instrument for sustainable urban development and management. In: Mosha A (ed) A reappraisal of the urban planning process. UN Habitat, New York

De Coninck H, Fischer C, Newell R, Ueno T (2008) International technology-oriented agreements to address climate change. Energy Policy 36(1):335-356

Devuyst D, Hens L, De Lannoy W (eds) (2001) How green is the city: sustainability assessment and the management of urban environments. Columbia University Press, New York

Dizdaroglu D, Yigitcanlar T, Dawes L (2012) A micro-level indexing model for assessing urban ecosystem sustainability. Smart Sustain Built Environ 1(3):291-315

Doughty M, Hammond G (2004) Sustainability and the built environment at and beyond the city scale. Build Environ 39(10):1223-1233

Dovers S (2005) Environment and sustainability policy: creation, implementation, evaluation. Federation Press, London

Dur F, Yigitcanlar T (2014) Assessing land-use and transport integration via a spatial composite indexing model. Int J Environ Sci Technol. doi:10.1007/s13762-013-0476-9

Ebert U, Welsch H (2004) Meaningful environmental indices: a social choice approach. J Environ Econ Manag 47(1):270-283

Elzen B, Geels F, Green K (eds) (2004) System innovation and the transition to sustainability: theory, evidence and policy. Edward Elgar, London

Fainstein S (2000) New directions in planning theory. Urban Aff Rev 35(4):451-478
Fainstein S (2005) Planning theory and the city. J Plan Educ Res 25(2):121-130

Farr D (2012) Sustainable urbanism: urban design with nature. Wiley, London

Fiksel J (2006) Sustainability and resilience: toward a systems approach. Sustainability 2(2):14-21

Flint J, Raco M (eds) (2012) The future of sustainable cities: critical reflections. The Policy Press, London

Gasparatos A (2010) Embedded value systems in sustainability assessment tools and their implications. J Environ Manag 91(1):1613-1622

Geertman S, Toppen F, Stillwell J (2013) Planning support systems for sustainable urban development. Springer, London

Gore T, Nicholson D (1991) Models of the land development process: a critical review. Environ Plan A 23(5):705-730

Hacking T, Guthrie P (2008) A framework for clarifying the meaning of triple bottom-line: integrated, and sustainability assessment. Environ Impact Assess Rev 28(1):73-89

Hamin E, Gurran N (2009) Urban form and climate change: balancing adaptation and mitigation in the US and Australia. Habitat Int 33(3):238-245

Hennicke P (2005) Long-term scenarios and options for sustainable energy systems and for climate protection: a short overview. Int J Environ Sci Technol 2(2):181-191

Huang P, Shih L (2009) Effective environmental management through environmental knowledge management. Int $\mathrm{J}$ Environ Sci Technol 6(1/3):35-50

Jabareen Y (2006) Sustainable urban forms: their typologies, models, and concepts. J Plan Educ Res 26(1):38-52

Jenks M, Dempsey N (eds) (2005) Future forms and design for sustainable cities. Routledge, London

Karol P, Brunner J (2009) Tools for measuring progress towards sustainable neighbourhood environments. Sustainability 1(1):612-627

Kenworthy J (2006) The eco-city: ten key transport and planning dimensions for sustainable city development. Environ Urban 18(1):67-85

Lawrence D (2000) Planning theories and environmental impact assessment. Environ Impact Assess Rev 20(1):607-625

Lee S, Yigitcanlar T, Hoon H, Taik L (2008) Ubiquitous urban infrastructure: infrastructure planning and development in Korea. Innovation 10(2/3):282-292

Li F, Liu X, Hu D, Wang R, Yang W, Li D (2009) Measurement indicators and an evaluation approach for assessing urban sustainable development. Landsc Urban Plan 90(3/4):134-142

Liao C, Chang C, Su C, Chiueh P (2013) Correlation between landuse change and greenhouse gas emissions in urban areas. Int $\mathrm{J}$ Environ Sci Technol 10(6):1275-1286

Luck G (2007) A review of the relationships between human population density and biodiversity. Biol Rev 82(1):607-645

Lyle J (1994) Regenerative design for sustainable development. Wiley, London

Mahbub P, Goonetilleke A, Ayoko G, Egodawatta P, Yigitcanlar T (2011) Analysis of build-up of heavy metals and volatile organics on urban roads in Gold Coast, Australia. Water Sci Technol 63(9):2077-2085

Mascarenhas A, Coelho P, Subtil E, Ramos T (2010) The role of common local indicators in regional sustainability assessment. Ecol Indic 10(3):646-656

Mayer A (2008) Strengths and weaknesses of common sustainability indices for multidimensional systems. Environ Int 34(1):277-291

Meadows D, Meadows H, Randers J, Behrens W (1972) The limits to growth: a report to the Club of Rome. Universe Books, New York 
Meehl G, Stocker T, Collins W, Friedlingstein P, Gaye A, Gregory J, Zhao Z (2007) Global climate projections. Clim Chang 13(1):747-845

Moore S (2007) Alternative routes to the sustainable city: Austin, Curitiba, and Frankfurt. Lexington Books, London

Mori K, Christodoulou A (2011) Review of sustainability indices and indicators: towards a new city sustainability index. Environ Impact Assess Rev 32(1):94-106

Muller F (1992) Hierarchical approaches to ecosystem theory. Ecol Model 63(1):215-242

Naess P (2001) Urban planning and sustainable development. Eur Plan Stud 9(4):503-524

Navabakhsh M, Tamiz R (2013) Influences of rural industries on sustainable social and environmental developments. Int $\mathrm{J}$ Environ Sci Technol 10(1):191-198

Neufeld D, Cockfield R, Fox B, Whitelaw G (1994) Towards an ecosystem approach to land-use planning. Ministry of Environment and Energy, Toronto

Newman P, Jennings I (2008) Cities as sustainable ecosystems: principles and practices. Island Press, Washington, DC

Nguyen L (2004) Environmental indicators for ASEAN: developing an integrated framework. United Nations University, Tokyo

Niemela J (1999) Ecology and urban planning. Biodivers Conserv 8(1):119-131

Nouri J, Karbassi A, Mirkia S (2008) Environmental management of coastal regions in the Caspian Sea. Int J Environ Sci Technol $5(1): 43-52$

Odum E (1989) Ecology and our endangered life support systems. Sinauer Associates, Boston, MA

Ortiz O, Castells F, Sonnemann G (2009) Sustainability in the construction industry: a review of recent developments based on LCA. Constr Build Mater 23(1):28-39

Peptenatu D, Pintilu R, Draghici C (2011) Environmental risk management of urban growth poles regarding national importance. Int J Environ Sci Technol 8(4):737-746

Pezzey J (2004) Sustainability policy and environmental policy. Scand J Econ 106(2):339-359

Pickett S, Grooge J (2009) Urban ecosystems: what would Tansley do? Urban Ecosyst 12(1):1-8

Pickett S, Cadenasso M, Grove J, Nilon C, Pouyat R, Zipperer W, Costanza R (2001) Urban ecological systems: linking terrestrial ecological, physical, and socioeconomic components of metropolitan areas. Annu Rev Ecol Syst 13(1):127-157

Pickett S, Cadenasso M, Grove J (2004) Resilient cities: meaning, models, and metaphor for integrating the ecological, socio-economic, and planning realms. Landsc Urban Plan 69(4):369-384

Rapport D, Gaudet C, Constanza R, Epstein P, Levins R (eds) (2009) Ecosystem health: principles and practice. Wiley, London

Rassafi A, Vaziri M (2005) Sustainable transport indicators: definition and integration. Int J Environ Sci Technol 2(1):83-96

Ratcliffe J, Stubbs M (2013) Urban planning and real estate development. Routledge, London

Redclift M (2005) Sustainable development (1987-2005): an oxymoron comes of age. Sustain Dev 13(4):212-227

Ridd M (1995) Exploring a V-I-S (vegetation-impervious surfacesoil) model for urban ecosystem analysis through remote sensing: comparative anatomy for cities. Remote Sens 16(12):2165-2186

Rotmans J, Van Asselt M (2000) Towards an integrated approach for sustainable city planning. J Multi-Criteria Decis Anal 9(3):110-124

Runhaar H, Driessen P, Soer L (2009) Sustainable urban development and the challenge of policy integration: an assessment of planning tools for integrating spatial and environmental planning in the Netherlands. Environ Plan 36(3):417-431
Rydin Y (2003) Conflict, consensus, and rationality in environmental planning: an institutional discourse approach: an institutional discourse approach. Oxford University Press, Oxford

Rydin Y (2010) Governing for sustainable urban development. Earthscan, London

Schonwandt W (2008) Planning in crisis: theoretical orientations for architecture and planning. Ashgate, Aldershot, UK

Shepherd G (2004) The ecosystem approach: five steps to implementation. International Union for Conservation of Nature, Gland

Singh R, Murty H, Gupta S, Dikshit A (2009) An overview of sustainability assessment methodologies. Ecol Indic 9(1): $189-212$

Teriman S (2012) Measuring neighbourhood sustainability: a comparative analysis of residential types in Malaysia. Unpublished $\mathrm{PhD}$ thesis, Queensland University of Technology, Brisbane, Australia

Teriman S, Yigitcanlar T (2011) Social infrastructure planning and sustainable communities: experience from South East Queensland, Australia. World J Soc Sci 1(4):23-32

Teriman S, Yigitcanlar T, Mayere S (2009) Urban sustainability and growth management in South-East Asian city-regions: the case of Kuala Lumpur and Hong Kong. Plan Malays $7(1): 47-68$

Tuzkaya U (2009) Evaluating the environmental effects of transportation modes using and integrated methodology and an application. Int J Environ Sci Technol 6(2):277-290

Tzoulas K, Korpela K, Venn S, Yli-Pelkonen V, Kazmierczak A, Niemela J, James P (2007) Promoting ecosystem and human health in urban areas using green infrastructure: a literature review. Landsc Urban Plan 81(3):167-178

Vasishth A (2008) A scale-hierarchic ecosystem approach to integrative ecological planning. Prog Plan 70(3):99-132

Wheeler S (2004) Planning for sustainability: creating livable, equitable, and ecological communities. Routledge, New York

Wheeler S, Beatley T (eds) (2004) The sustainable urban development reader. Routledge, New York

While A, Jonas A, Gibbs D (2010) From sustainable development to carbon control: ecostate restructuring and the politics of urban and regional development. Trans Inst Br Geogr 35(1):76-93

Williams K, Burton E, Jenks M (2000) Achieving sustainable urban form. Routledge, New York

Wu J (2008) Making the case for landscape ecology an effective approach to urban sustainability. Landsc J 27(1):41-50

Yigitcanlar T (ed) (2010a) Sustainable urban and regional infrastructure development. IGI-Global, Hersey, PA

Yigitcanlar T (ed) (2010b) Rethinking sustainable development. IGIGlobal, Hersey, PA

Yigitcanlar, T, Lee S (2013) Korean ubiquitous-eco-city: a smartsustainable urban form or a branding hoax? Technol Forecast Soc Chang doi:10.1016/j.techfore.2013.08.034

Yigitcanlar T, Dur F (2010) Developing a sustainability assessment model: the sustainable infrastructure land-use environment and transport model. Sustainability 2(1):321-340

Yigitcanlar T, Dodson J, Gleeson B, Sipe N (2007a) Travel selfcontainment in master planned estates: analysis of recent Australian trends. Urban Policy Res 25(1):133-153

Yigitcanlar T, Sipe N, Evans R, Pitot M (2007b) A GIS-based landuse and public transport accessibility indexing model. Aust Plan 44(3):30-37

Yigitcanlar T, Fabian L, Coiacetto E (2008) Challenges to urban transport sustainability and smart transport in a tourist city: the Gold Coast. Open Transp J 2(1):29-46

Yigitcanlar T, Rashid K, Dur F (2010) Sustainable urban and transport development for transportation disadvantaged: a review. Open Transp J 4(1):78-86 
Zhang Y, Yang Z, Yu X (2006) Measurement and evaluation of interactions in complex urban ecosystem. Ecol Model 196(1):77-89
Zhao P (2010) Sustainable urban expansion and transportation in a growing megacity: consequences of urban sprawl for mobility on the urban fringe of Beijing. Habitat Int 34(2):236-243 